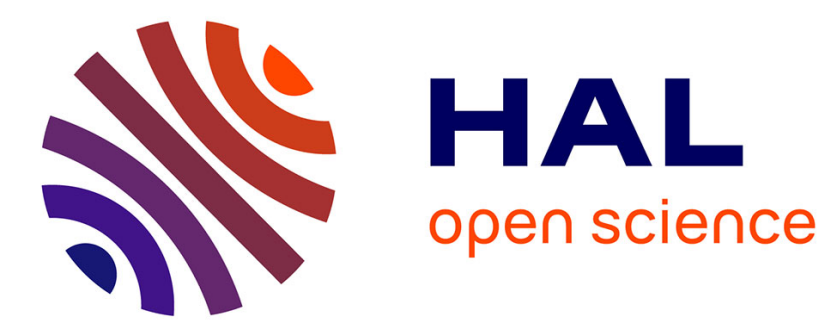

\title{
Space and habitat use of moose in southwestern Sweden
}

Mattias Olsson, John J. Cox, Jeffery L. Larkin, Per Widén, Anders Olovsson

\section{To cite this version:}

Mattias Olsson, John J. Cox, Jeffery L. Larkin, Per Widén, Anders Olovsson. Space and habitat use of moose in southwestern Sweden. European Journal of Wildlife Research, 2010, 57 (2), pp.241-249. 10.1007/s10344-010-0418-5 . hal-00608409

\section{HAL Id: hal-00608409 \\ https://hal.science/hal-00608409}

Submitted on 13 Jul 2011

HAL is a multi-disciplinary open access archive for the deposit and dissemination of scientific research documents, whether they are published or not. The documents may come from teaching and research institutions in France or abroad, or from public or private research centers.
L'archive ouverte pluridisciplinaire HAL, est destinée au dépôt et à la diffusion de documents scientifiques de niveau recherche, publiés ou non, émanant des établissements d'enseignement et de recherche français ou étrangers, des laboratoires publics ou privés. 


\title{
Space and habitat use of moose in southwestern Sweden
}

\author{
Mattias Olsson • John J. Cox • Jeffery L. Larkin • \\ Per Widén • Anders Olovsson
}

Received: 29 September 2009 /Revised: 23 June 2010 / Accepted: 1 July 2010 /Published online: 13 July 2010

(C) Springer-Verlag 2010

\begin{abstract}
Increasingly, wildlife managers and land managers are challenged to maintain the viability of large mammal populations. Although the moose (Alces alces) is an ecologically, economically, and culturally important ungulate species found throughout most of Sweden, little is known about its ecology throughout the southern part of the country. We collected baseline ecological data on spatial and habitat use patterns in urbanized southwestern Sweden by fitting 22 adult moose (13 F, nine M) with global positioning system (GPS) radio collars. Home range size of cows did not differ among seasons $(P>0.10)$; however, bulls had larger home ranges during fall than all other seasons $(P<0.010)$. Mean home range size of males during
\end{abstract}

Communicated by H. Kierdorf

M. Olsson $(\varangle) \cdot$ A. Olovsson

Department of Biology, Karlstad University,

65188 Karlstad, Sweden

e-mail: Mattias.Olsson@kau.se

A. Olovsson

e-mail: cinclus@telia.com

J. J. Cox

Department of Forestry, University of Kentucky,

208 T.P. Cooper Building,

Lexington, KY 40546-0073, USA

e-mail: jjcox@uky.edu

\section{J. L. Larkin}

Department of Biology, Indiana University of Pennsylvania, Indiana, PA 15705, USA

e-mail: larkin@iup.edu

\section{P. Widén}

Department of Health and Environmental Sciences,

Karlstad University,

65188 Karlstad, Sweden

e-mail: perw@kau.se fall and spring was larger than females during any season $(P<0.010)$. We used a Euclidean distance-based approach to analyze multi-scale habitat selection by moose. Moose of both sexes and during all seasons selected boreal forest and mires when establishing a home range $(P<0.10)$. Moose had seasonal differences in habitat selection within their home range $(P 0.001)$, and generally selected clear-cuts and early successional forests, mature coniferous forests, and glades, but avoided agricultural areas and open water. Habitat and space use characteristics of moose in our urbanizing study area were similar to characteristics reported for moose in forest-dominated landscapes of Fennoscandia.

Keywords Alces alces - Global positioning system . Habitat $\cdot$ Home range $\cdot$ Moose $\cdot$ Radiotelemetry

\section{Introduction}

Characterization of space and habitat use patterns of large, mobile mammals is an important research goal in areas with intense human land use patterns, where urbanization and competing land uses increasingly challenge wildlife managers to maintain connectivity within a population (Davies et al. 2001; Harveson et al. 2007). This is the case particularly in areas where human development and areasensitive wildlife populations interface (Meegan and Maehr 2002; Maehr et al. 2002; Harveson et al. 2007). Exurban development is increasing throughout much of the developed world (Hilty et al. 2006). In fact, the number of suburban residents in some European countries has increased threefold over the past 50 years (Hilty et al. 2006). Fragmentation and habitat loss associated with permanent landscape-scale alterations such as roads, agri- 
culture, and urban areas can inhibit habitat connectivity, reduce carrying capacity, and isolate wildlife populations (Saunders et al. 1991). These conditions can affect survival, daily and season movements, dispersal, the use of otherwise available habitat, and ultimately result in local extinction. (Saunders et al. 1991; Mills 2007).

Increased noise levels and human activities associated with human development and supporting infrastructures are known to have negative impacts on large mammal populations. For example, avoidance of areas due to highway disturbances have been documented for black bear (Ursus americanus), gray wolf (Canis lupus), and bobcat (Felis rufus) (Brody and Pelton 1989; Thurber et al. 1994; Lovallo and Anderson 1996; Mladenoff et al. 1999; Orlando 2003). Additionally, urban development was reported as the greatest threat to Florida key deer (Odocoileus virginianus clavium) population viability (Lopez et al. 2003), but the threshold level of urbanization had not yet been reached (Harveson et al. 2007). Nonetheless, effects of risks associated with urbanizing landscapes may threaten the viability of large mammal populations unless appropriate land use planning is employed (Meegan and Maehr 2002; Larkin et al. 2004). An important requirement for creating regional land use plans that consider wildlife conservation is the identification of threshold levels of human development that, if surpassed, have potentially unsustainable consequences for wildlife populations (Harveson et al. 2007).

The moose (Alces alces) is the largest member of family Cervidea and inhabits boreal forest-dominated regions of North America, Europe, and Asia (Franzmann and Schwartz 1997). The species was nearly extirpated from Sweden during 1800 s due to over-harvest, but hunting regulations prevented the loss of moose from the Swedish landscape (Lavslund et al. 2003). Habitat improvements created by modern forestry techniques, changes in sex- and age-specific harvest regulations, and lack of native predators such as the wolf and brown bear (Ursus arctos) have been identified as important factors that have been responsible for dramatic increases in Swedish moose population since the 1960s (Lavslund et al. 2003). However, in southwestern Sweden human population growth and concomitant pressures from infrastructure and development in or near coastal areas encroach upon moose habitat.

The goal of our study was to evaluate whether current levels of human development and associated infrastructure in an area of southwestern Sweden were intense enough to have impacted local moose ecology. We used GPS telemetry and GIS technology to characterize moose space and habitat use in an urbanizing area of coastal southwestern Sweden, where anthropogenic pressures increasingly threaten to fragment and isolate local moose populations.
Hundertmark (1998) hypothesized that moose living in habitats characterized by relatively poor productivity (lower carrying capacity) would have larger home ranges than conspecifics in more productive habitats. As such, we predicted that moose resource selection and space use in our urbanizing study area would differ from values reported for moose populations in more forested regions of Fennoscandia if the human development threshold for the species had been surpassed. Information gained from our study provides wildlife managers and land use planners insight that can be used to develop more effective conservation plans that promote viable moose populations in this region.

\section{Materials and methods}

\section{Study area}

Our study was conducted in coastal southwestern Sweden between the cities of Uddevalla and Munkedal (Fig. 1). We defined the $320 \mathrm{~km}^{2}$ study area by generating a $100 \%$ minimum convex polygon (Mohr 1947), modified to exclude ocean, around all moose telemetry locations using the Animal Movement Extension (Hooge and Eichenlaub 2000) in ArcView 3.3 (ESRI, Redlands, CA). A $15 \mathrm{~km}$ section of European Highway 6 (E6) spanned the study area and also conveniently delineated the approximate boundary between boreonemoral and nemoral ecoregions (Abrahamsen et al. 1977). The landscape in this region was comprised of a mosaic of cover types including mature coniferous forest $(46.0 \%)$ agriculture $(19.0 \%)$, deciduous forest $(10.0 \%)$, early successional forest $(9.2 \%)$, glade $(7.4 \%)$, mires (3.6\%), open freshwater $(2.7 \%)$, and human development $(2.0 \%)$. The dominant tree species in the mature coniferous forest were Norway spruce (Picea abies) and Scots pine (Pinus sylvestris), with an intermixture of birch (Betula spp.), aspen (Populus tremula), willow (Salix spp.), and other deciduous species. The mature coniferous forest had a dwarf-shrub layer dominated by bilberry (Vaccinium myrtillus), cowberry (Vaccinium vitis-idaea), or heather (Calluna vulgaris). The deciduous forest stands were dominated by birch, rowan (Sorbus aucuparia), willow, common aspen, common alder (Alunus glutinosa), and pendunculate oak (Quercus robur). The early successional stages of forest after logging had a high abundance of birch, rowan, willow, and other deciduous species, with an herbaceous layer of wavy hair grass (Deschapsia flexuosa). However, within 3 years after logging, these stands were planted (or self generated) with either Norway spruce or Scots pine and thereafter managed to favor those species. Agricultural areas were comprised of hay and pastureland composed of a mosaic of grasses that commonly included 
Fig. 1 GPS-telemetry locations of moose in southwestern Sweden, from 5 Feb 2002 thru 15 Dec 2005. Shaded polygons represent major city boundaries

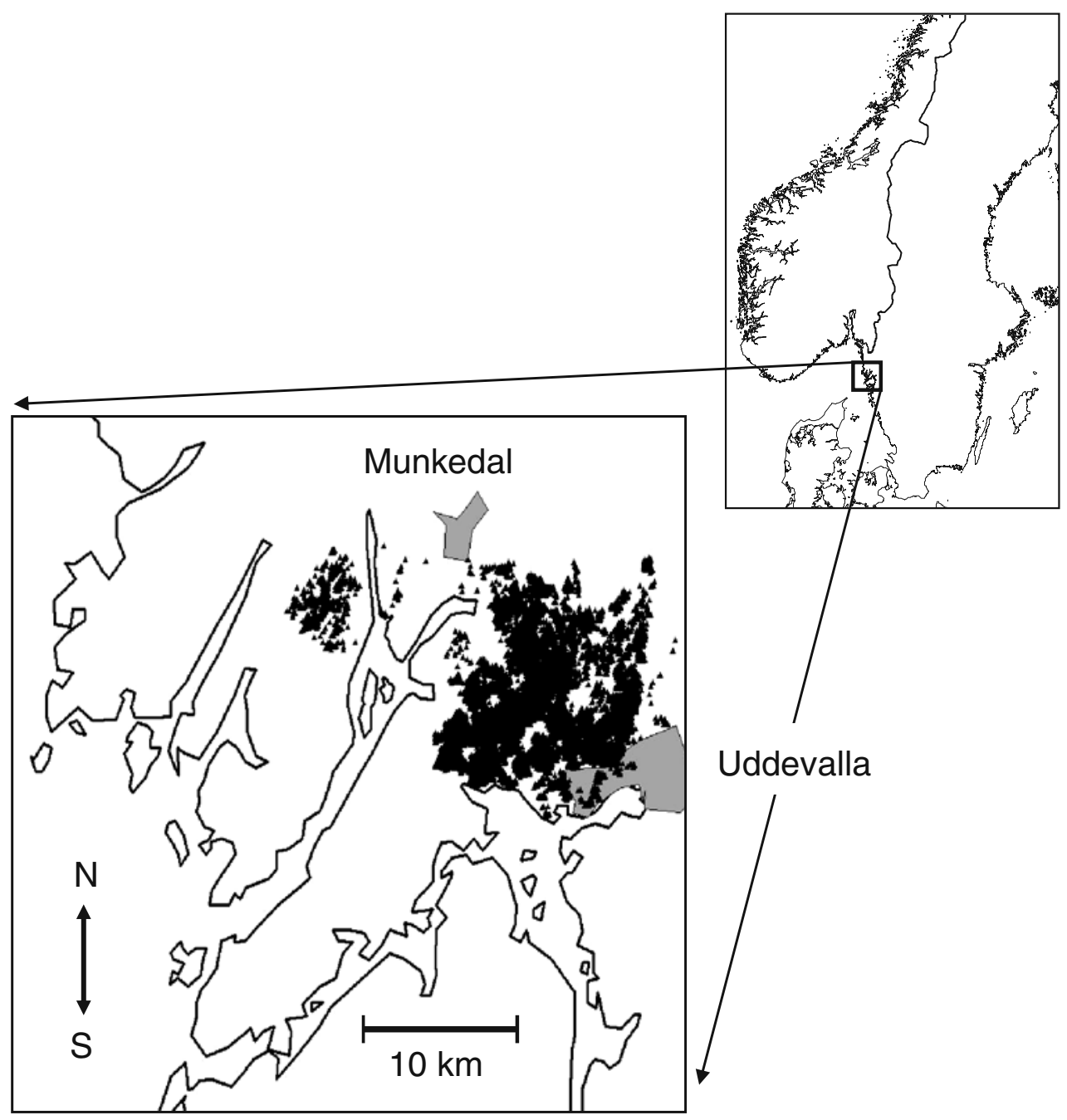

perennial rye (Poa pretensis), quackgrass (Elytrigia repens), orchardgrass (Dactylis glomerata), and timothy (Phleum pratense), and crops that primarily included wheat (Triticum aestivum), barley (Avena sativa), oats (Horedelymus vulgare), and rye (Secale cereal).

Elevation within the study area ranged between $0-169 \mathrm{~m}$ above sea level. The most important human activities thought to influence biota in the study area were forestry, agriculture, infrastructure, and urban development. A helicopter inventory of moose density and sex/age classes conducted in February 2004 indicated an average moose density of $0.83 \mathrm{moose} / \mathrm{km}^{2}$ in the study area (Anonymous 2004).

\section{Capture and radio-collaring}

We used a helicopter-based aerial platform to shoot and immobilize 24 moose $(14 \mathrm{~F}$, ten $\mathrm{M})$ with a dart containing Large Animal Immobilon ${ }^{\mathrm{TM}}$ (Etorfin hydrochlorid $2.45 \mathrm{mg} / \mathrm{ml}$, Acepromazin $10 \mathrm{mg} / \mathrm{ml}$, and Xylazine $100 \mathrm{mg} / \mathrm{ml}$; C-vet Ltd. Leyland, UK) in a $55 \mathrm{~km}^{2}$ area during February
2002, 2003, and 2004. Each captured moose was equipped with a non-differentially-corrected GPS collar (GPSSIMPLEX ${ }^{\mathrm{TM}}$; Televilt Positioning AB Inc., Lindesberg, Sweden) programmed to obtain a geographical location every $2 \mathrm{~h}$ and equipped with a pre-programmed electronic breakaway device. Data collected with each location included date, time, satellite geometry, and fix status based on communication with GPS satellites. Mean position accuracy of non-differentially-corrected GPS-SIMPLEX ${ }^{\mathrm{TM}}$ collars were tested in similar forest habitats in France. The mean location error for 2D locations with $\mathrm{DOP}<5$ was $13.1 \mathrm{~m}$ $(\mathrm{SE}= \pm 1.7 \mathrm{~m})$, and $8.8 \mathrm{~m}(\mathrm{SE}= \pm 0.5 \mathrm{~m})$ for $3 \mathrm{D}$ with $\mathrm{DOP}<5$ (Janeau et al. 2001).

Moose locations were collected year-round from $5 \mathrm{Feb}$ 2002 thru 15 Dec 2005 and included 71,103 locations of 22 adult (aged $2-13$ years) moose ( $13 \mathrm{~F}$, nine $\mathrm{M}$ ). Moose GPSdata were divided into four seasons based on climate (Swedish Meteorological and Hydrological Institute) and moose biology: spring (16 March-15 May); summer (16 May-31 August); fall (1 September-30 November); and winter (1 December-15 March) (Pulliainen 1974; 
Cederlund and Okarma 1988). Summer period was adjusted to the vegetation period and the calving season that starts in the middle of May. The fall period was adjusted to the rut.

\section{Data analysis}

Moose were located approximately every 2 months from the ground to download radio-collar data. GPS collar locations with $2 \mathrm{D}$ fixes and a DOP $>7(n=1402)$ were removed from the dataset. We used a Euclidean distancebased analysis (EDA) to measure actual Euclidean distances to land cover types classified on digitized land cover maps (Conner and Plowman 2001; Cox et al. 2006). The digital land use map used in our analyses was developed by Swedish National Land Survey using Landsat Thematic Mapper Satellite Data collected from 2000-2002 and contained 57 land use classes at a pixel size of $25 \mathrm{~m} \times$ $25 \mathrm{~m}$ and a classification accuracy $>75 \%$ (Anonymous 1999; Engberg 2002). Our study area contained 34 of the original 57 land use classes. We reclassified the study area land cover data map into eight general cover types most likely to influence moose. Reclassified cover types included mature coniferous forest, mature deciduous forest, early successional forest (including clear-cuts), agriculture, urban areas, open water, mire, and glades (bare rock-upper elevated areas with shallow soils and rock outcrops dominated by heath (Calluna vullgaris) and lichens with $<30 \%$ tree cover) (Appendix).

We initially generated moose home ranges via the kernel method, but the resulting home ranges excluded areas where radio-collared moose were observed. As such, after visual comparison with kernel-based methods, we determined that the $100 \%$ minimum convex polygon (MCP) was the appropriate method to delineate moose home ranges. According to the resource selection literature it is more correct to include unused areas than to exclude areas that are known to be used by moose (Porter and Church 1987; Manly et al. 2002; Land et al. 2008). Excluding areas known to be used by radio-collared individuals is problematic from a resource selection perspective (Porter and Church 1987; Manly et al. 2002). Thus, we generated $100 \%$ MCP seasonal home ranges $(n=133)$ and a composite home range using all location data for moose monitored $\geq 1$ year $(n=16)$ using the Animal Movement Analysis (Hooge and Eichenlaub 2000) for ArcView 3.3 (ESRI, Redlands, California) (Table 1). Home ranges were generated only for time periods with $\geq 50$ locations per season. Mean seasonal home range sizes were calculated across years and resulted in 82 seasonal home ranges used in the statistical analysis. A Wilcoxon signed-rank test for matched pairs was used to test for differences in moose annual home range size between consecutive years $(n=12)$; males $(n=2)$ were pooled with females $(n=10)$ due to low sample size of the former. A Mann-Whitney $U$ test was used to test for differences in annual composite home range size between sexes. We used a two-way analysis of variance (ANOVA) to test for seasonal differences of home range size between sexes, among seasons, or within a sex $\times$ season interaction.

We estimated second order (selection of the home range) and third-order (selection within the home range) habitat selection following Johnson (1980). Our Euclidean distance-based habitat analysis was conducted as follows. Firstly, we used the random point generator of the Animal Movement Extension for ArcView 3.3 to create 50,000 random locations throughout the moose study area and 1,000 random locations within each moose home range. We then used the Nearest Feature Extension (Jenness Enterprises 2004) to calculate the Euclidean distance (m) of each random point and moose location to the nearest polygon of each land cover class. Points were valued as $0 \mathrm{~m}$ if they occurred within a habitat. To determine second order habitat selection, we created 8 distance ratios (1 per habitat type) for each moose by dividing the average distances from random locations within each individual home range by the average distances from random locations throughout the study area. To determine thirdorder habitat selection, we created 8 distance ratios for each moose by first calculating an average distance of moose locations to each habitat, and then dividing it by the average distances from random locations within each individual home range. We used ANOVA with multiple explanatory variables in program SAS version 8.2 (SAS Institute, Cary, North Carolina) to test the hypothesis that overall habitat selection did not differ from random with sex and season as main effects and individual moose as the experimental unit. When season or the $\operatorname{sex} \times$ season interaction was not found as a significant main effect, we tested habitat use differences between sexes based on the composite home range for each individual moose. If our model was significant, univariate $t$ tests were used to determine which habitats were used disproportionately. Habitat types with distance ratios significantly $<1$ were selected, and those significantly $>1$ were avoided. Habitat types were ranked by performing pairwise mean comparisons using univariate $t$ tests (Conner and Plowman 2001; Perkins and Conner 2004). We considered statistical significance for all analyses at $P \leq 0.10$.

\section{Results}

Home range size

We analyzed 22 adult moose ( $13 \mathrm{~F}$, nine $\mathrm{M})$ to determine sex, season $(n=133)$, and $\operatorname{sex} \times$ season interaction effects on 
Table 1 Seasonal and composite minimum convex polygon $(100 \%)$ home range sizes of moose in southwestern Sweden, 2002-2005
Mean seasonal home ranges across years per individual moose were used to eliminate pseudoreplication

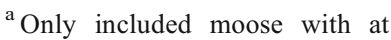
least 1 year of data

\begin{tabular}{lllll}
\hline Mean home & \multicolumn{3}{l}{} \\
\hline Sex & Number of moose seasons & Time period & Range size $\left(\mathrm{km}^{2}\right)$ & SE \\
\hline Females & 26 & Spring & 10.6 & 12.0 \\
& 22 & Summer & 7.0 & 3.6 \\
& 19 & Fall & 12.5 & 17.0 \\
& 25 & Winter & 5.7 & 5.1 \\
Males & 10 & Composite & \\
& 11 & Spring & 15.6 & 2.6 \\
& 9 & Summer & 20.6 & 21.2 \\
& 9 & Fall & 17.6 & 10.0 \\
& 12 & Winter & 7.7 & 21.0 \\
& 6 & Composite & \\
& & & 52.2 & 5.7 \\
\end{tabular}

home range size. We found a significant sex $\times$ season interaction effect on moose home range size $\left(F_{7,125}=\right.$ $6.93, P<0.001)$. Home range size of females did not differ among seasons $(P>0.10)$, however, males had larger home ranges during fall than all other seasons $(P<0.010)$ (Table 1). Mean home range size of males during fall and spring was larger than females during any season $(P<0.010)$.

Adult moose (ten $\mathrm{F}$, two $\mathrm{M}$ ) did not differ in annual home range size between consecutive years $(T=23, P=0.21)$. Males $\left(n=6 ; 52.2 \mathrm{~km}^{2} \pm 10.9 \mathrm{~km}^{2}\right)$ had larger mean composite home ranges than females $\left(n=10 ; 15.6 \mathrm{~km}^{2} \pm 2.6 \mathrm{~km}^{2}\right)(U=3$, $P<0.05$; Table 1).

\section{Habitat use}

We determined season and sex $\times$ season interaction effects on second and third-order habitat selection of 22 (13 F, nine $\mathrm{M})$ adult moose. Season $\left(F_{24,183}=0.76, P=0.779\right)$ and the sex $\times$ season interaction $\left(F_{24}, 183=0.42, P=0.992\right)$ did not affect second order habitat selection, and consequently, we pooled data across seasons within the composite home range of each individual and examined sex effects on second order habitat selection. Although we found no differences between sexes $\left(F_{8,13}=1.26, P=0.341\right)$, moose home ranges included some habitats more than expected $\left(F_{8},{ }_{14}=6.15, P=0.002\right)$ (Table 2). There were more mature coniferous forest $\left(t_{21}=-2.71, P=0.013\right)$ and mires $\left(t_{21}=-2.37, P=0.027\right)$ in home ranges compared with the overall landscape, but no difference between these two habitats was found $(P=0.805)$.

Season $\left(F_{24}, 183=1.59, P=0.047\right)$ was found to affect third-order habitat selection, but the sex $\times$ season interaction did not $\left(F_{24}, 183=1.27, P=0.189\right)$, and consequently, we pooled sexes within season. Moose selected habitats within their home ranges during each season (spring, $F_{8,14}=12.84, P<0.001$; summer, $F_{8,12}=4.30, P=0.012$; fall, $F_{8,10}=3.08, P=0.050$; winter, $\left.F_{8,10}=30.57, P<0.001\right)$ (Table 2). During spring, moose selected mature coniferous forest $\left(t_{21}=-4.00, P<0.001\right)$ over glades $\left(t_{21}=-5.63\right.$, $P<0.001)$ and early successional forest $\left(t_{21}=-3.88\right.$, $P<0.001)$ and avoided agriculture $\left(t_{21}=4.92, P<0.001\right)$. During summer, moose selected early successional forest $\left(t_{19}=-5.14, P<0.001\right)$ over deciduous forest $\left(t_{19}=-2.35\right.$, $P=0.030)$ and avoided open water $\left(t_{19}=2.25, P=0.037\right)$. During fall, moose selected early successional forest $\left(t_{17}=-3.98, P<0.001\right)$ over urban areas $\left(t_{17}=-1.77\right.$, $P=0.094)$ and avoided mires $\left(t_{17}=1.88, P=0.077\right)$ and agriculture $\left(t_{17}=1.81, P=0.088\right)$. During winter, moose selected early successional forest $\left(t_{17}=-5.12, P<0.001\right)$ over other habitats but avoided mires $\left(t_{17}=1.87, P=0.079\right)$ and agriculture $\left(t_{17}=-4.00, P<0.001\right)$.

Moose used mature coniferous forest $\left(F_{3,74}=3.51\right.$, $P=0.020)$, agriculture $\left(F_{3,74}=4.99, P=0.003\right)$, glades $\left(F_{3,74}=\right.$ 2.60, $P=0.058)$, and urban areas $\left(F_{3,74}=2.82, P=0.045\right)$ differently by season (Table 2). Post-hoc analysis revealed that differences in seasonal habitat selection occurred in use of mature coniferous forest $(P=0.020)$ and urban areas $(P=0.070)$ during spring and fall, in use of mature coniferous forest $(P=0.096)$, agriculture $(P=$ $0.002)$, glades $(P=0.091)$, and urban areas $(P=0.090)$ during spring and summer, and in use of glades $(P=0.087)$ during spring and winter.

We also examined third-order habitat selection of 16 moose (ten F, six M) using composite home ranges for those individuals with at least one complete year of telemetry data. We pooled data between sexes because the number of males was less than the number of habitat variables. Moose selected habitats within their home ranges $\left(F_{8,8}=6.54, P=0.008\right)$. Moose equally selected early successional forest $\left(t_{21}=-7.70\right.$, $P<0.001)$ and mature coniferous forest $\left(t_{21}=-4.71\right.$, $P<0.001)$ over glades $\left(t_{21}=-2.03, P=0.061\right)$, but avoided open water $\left(t_{21}=2.08, P=0.060\right)$ (Table 2). 
Table 2 Johnson's (1980) second- and third-order habitat selection by moose in southwestern Sweden, 2002-2006

Habitat selection order Season Habitat ranking

\begin{tabular}{lll}
\hline 2nd & - & MIR $(0.73)>$ CFR $(0.75)>$ AGR $(0.90)>\operatorname{ESF}(0.97)$, GLD $(0.97)>$ WAT $(0.98)>>$ DFR $(1.05)>$ URB $(1.07)$ \\
$3 \mathrm{rd}^{\mathrm{a}}$ & SP & CFR $(0.67)>>$ GLD $(0.84)>$ ESF $(0.85)>>$ WAT $(0.99)>$ MIR $(1.01)>$ DFR $(1.04)>$ URB $(1.08)>>$ AGR $(1.38)$ \\
& SU & ESF $(0.73)>>$ DFR $(0.90)>>$ CFR $(0.93)>$ URB $(0.94)>$ GLD $(1.00)>$ AGR $(1.01)>$ MIR $(1.06)>$ WAT $(1.07)$ \\
& FA & ESF $(0.82)>>$ URB $(0.92)>$ GLD $(0.93)>$ DFR $(0.94)>$ CFR $(1.00)>$ WAT $(1.07)>>$ MIR $(1.13)>$ AGR $(1.15)$ \\
& WI & ESF $(0.79)>$ CFR $(0.92)>$ URB $(0.96)>$ DFR $(0.99)>$ GLD $(1.00)>$ WAT $(1.06)>$ MIR $(1.08)>$ AGR $(1.15)$ \\
$3 \mathrm{rd}^{\mathrm{b}}$ & - & ESF $(0.69)>$ CFR $(0.70)>>$ GLD $(0.89)>$ DFR $(0.94)>$ URB $(0.99)>$ MIR $(1.03)>$ AGR $(1.11)>$ WAT $(1.13)$ \\
\hline
\end{tabular}

Habitat types in bold had a distance ratio (in parentheses) that differed significantly $(P \leq 0.10)$ from 1.00

$S P$ spring, $S U$ summer, $F A$ fall, $W I$ winter, $C F R$ mature coniferous forest, $A G R$ agriculture, $D F R$ deciduous forest, $E S F$ early successional forest, GLD glade, MIR mire, $U R B$ urban areas, WAT open water, $(>)$ a rank-order difference with $P \geq 0.10,(>>) P \leq 0.10$

${ }^{\mathrm{a}}$ Using seasonal home ranges

${ }^{\mathrm{b}}$ Using composite home ranges

\section{Discussion}

\section{Home range size}

Despite our predictions, habitat and space use characteristics of moose in our urbanizing study area were similar to characteristics reported for moose in forest-dominated landscapes of Fennoscandia. Female composite home range sizes were similar to those reported in other regions of Sweden (Cederlund and Okarma 1988; Cederlund and Sand 1994). Male composite home range sizes appeared to be relatively large compared to other Fennoscandian studies (Cederlund and Sand 1994), but the low sample size $(n=6)$ precluded statistical comparison. Home range sizes of cervids typically differ between sexes because of different food requirements related to body size, predator avoidance strategies, and rearing of young (Cederlund and Sand 1994; Bowyer 2004). In this study, males had composite home range sizes more than three times larger than females, a pattern also observed by Cederlund and Sand (1994).

Female home ranges did not differ among seasons but it did for males. Male home ranges during fall were more than four times larger than home ranges during winter. During winter, movements may be reduced to conserve energy (Moen 1976) and be restricted by accumulated snow (Van Ballenberghe and Peek 1971). However, snow cover during the study never exceeded the amount that would impede moose movements (Kelsall 1969; Cederlund and Okarma 1988). In addition to the potential need for conservation of thermal energy, moose in this study may have reduced winter movements because important foraging habitats such as clear-cuts and early successional forests (Cederlund and Okarma 1988; Nikula et al. 2004) were common and evenly distributed throughout the study area.
Habitat use

Previous studies conducted in Fennoscandia have documented moose habitat selection at landscape (Nikula et al. 2004) and home range scales (Cederlund and Okarma 1988; Hjeljord et al. 1990) using VHF-telemetry. Recently, other studies (Van Beest et al. 2010) have assessed multi-scale habitat selection of moose using the potentially higher resolving technologies that GPS telemetry can provide.

When selecting home ranges, moose equally selected areas with more mature coniferous forest and mires than what was found on average in the study area. In general, moist coniferous forests and complexes of marsh-land have been identified as important moose habitats containing food and cover during snow-free (Markegren 1974; Bergström and Hjeljord 1987) and snow-covered periods (Bergström and Hjeljord 1987). Coniferous forest has been repeatedly shown to be important in providing shelter and forage for moose (Markegren 1974; Bergström and Hjeljord 1987, Nikula et al. 2004). During the 1960s, mires were first described as important winter habitat for moose (Bergström and Hjeljord 1987). Since that time, however, the emergence of young forests, and an increase in moose population densities and concomitant over-browsing of low-productive habitats are thought to have altered moose habitat preferences (Bergström and Hjeljord 1987) as reflected in a recent study which found that moose avoided mires when selecting a home range (Nikula et al. 2004). The selection of mires in our coastal study area might have occurred because of the strong correlation of boreal forest and mire habitats $\left(r^{2}=0.73\right)$, and because of the high relative proportion of agricultural land compared with other habitat types, especially west of highway E6.

Cederlund and Sand (1994) hypothesized that the intensive forestry that creates evenly distributed patches of 
clear-cuts with different successional stages at a scale smaller than a moose home-range would increase moose philopatry. In this study, moose did not prefer early successional forests when selecting a home range, a finding that may be a result of the relatively even distribution of that cover type throughout the study area.

Important factors of moose habitat selection include quality and quantity of palatable browse, predator avoidance, thermal protection, and snow depth (Bergström and Hjeljord 1987; Nikula et al. 2004). Moose selected habitats differently within seasonal home ranges and also selected habitats among seasons (Table 2), but no differences in seasonal habitat use were found between sexes. Moose selected early successional forests during all seasons and selected it over other habitat classes in summer and fall. In contrast to Nikula et al. (2004), who observed that moose used early successional pine-dominated plantations more in winter than summer, we found no difference in use of early successional forests among seasons. Clear-cut logging has historically created plant species communities similar to those found after forest fires (Peek 1997). Young forests in these timbered areas, particularly those dominated by pine, will remain an important component of moose diet, especially during winter (Cederlund and Okarma 1988; Nikula et al. 2004). In Fennoscandia, Scots pine is generally the most abundant forage resource during winter, and thus is usually most commonly browsed by moose (Cederlund et al. 1980; Bergström and Hjeljord 1987). In this study, coniferousdominated clear-cuts and early successional forests were not classified separately in the land cover data which may have reduced our ability to detect seasonal differences in use of this land cover type as found in previous studies.

Markegren (1974) considered mature forests important during snow-free periods because of the presence of palatable food plants in the shrub layer. Cederlund and Okarma (1988), however, reported no habitat selection of mature forest over other cover types. Hjeljord et al. (1990) addressed the importance of mature coniferous forest to moose in late summer, and hypothesized that the delayed phenological changes in selected food plants was the primary reason for this habitat selection pattern. In contrast, we observed that moose used mature coniferous forest significantly more during spring than in summer or fall (Table 2). Spring is often a crucial season for moose that seek to replenish energy reserves as typically evidenced in the sharp dietary shifts from less palatable winter forage to more palatable and nutritious spring forage as species become available after snow melt (Cederlund et al. 1980). Bilberry is an important early spring food for moose that is found in mature coniferous forest and that becomes available shortly after snow melt. Consumption of bilberry by moose in this study may explain our observations as to why mature coniferous forest was used more by moose in spring than other seasons.
We also found seasonal differences in habitat use of glade, agriculture and urban areas. Glades were selected during spring but not during other seasons, a pattern that may reflect increased selection of heather and juniper (Juniperus communis) in spring diet, coupled with summer and winter avoidance of these areas due to high temperatures and increased snow depth, respectively. Although agriculture was not selected relative to other cover types during any season, it was used at random during summer and significantly avoided during other seasons (Table 2). Oat-laden agricultural fields often attract moose during late summer and may be an important and nutritious food resource during this period (Bergström and Hjeljord 1987).

Moose were found closer to urban areas during summer and fall than in spring. Selection of these areas reflected an increased moose activity in rural areas during this period, and not in high density urban areas that moose always tended to avoid. In rural areas of Sweden, moose commonly forage on apples grown in gardens during late summer and early fall, a behavior supported by the frequent presence of moose tracks we observed in these areas during field work.

Spatial heterogeneity has been found to be an important predictor of ungulate distribution and foraging patterns (Turner et al. 1997; Mysterud et al. 1999; Kie et al. 2002). Our results support the findings of Hjeljord et al. (1990) that found a mix of older and younger forests to be important for moose. Hjeljord et al. (1990) observed that a heterogeneous mixture of clear-cuts, plantations and older forest may give moose an optimal choice of feeding sites during summer. Additionally, we found deciduous forest and non-forested ( $<30 \%$ forest cover) habitat such as glades to be seasonally important. Small scale forest management practices can create a dynamic mosaic of uneven-aged forest patches that could be more easily encompassed within the home range of moose and provide season-specific resources that can increase home range fidelity (Cederlund et al. 1987) and decrease dispersal to new areas (Gasaway et al. 1980) - two potentially important management goals in areas where reductions in human-moose encounters and sustainability of moose populations are concurrent goals.

EDA has become a commonly used method to determine coarse-scale wildlife habitat use patterns (Conner and Plowman 2001; Perkins and Conner 2004; Cox et al. 2006). EDA has been described as being more robust to telemetry error than classification-based analyses, but further evaluation of the type 1 error distribution, and the effects of spatial scaling, especially at the landscape level, is needed (Conner et al. 2003). Given the continued trends in rural-urban land use conversion that will likely occur in south Sweden in the near future, we suggest that future analyses temporally match land cover and telemetry data as closely as possible, and that land cover data be integrated and updated with field surveys in critical habitat areas 
where greater resolution of vegetation types (e.g., forest stand age and composition) may be needed. In doing so, the relative importance of moose habitats at finer scales could be better determined and management more locally adapted to prevailing conditions and circumstances.

Moose will likely remain an important economic and nutritional resource for Fennoscandian and other Holoarctic human societies. Wildlife and land managers responsible for maintaining a viable and harvestable population of moose in increasingly urbanized and denatured landscapes face imposing challenges. Our study and previous findings support the management strategy of creating and maintaining a mosaic of differing forest age classes and some nonforest cover types that will optimize cover and forage for moose during all seasons. However, we also recommend that managers consider the ecological impacts to species more sensitive to timber harvest before implementing moose-centric management plans. We further recommend researchers investigate the relationships among moose occurrence, spatial heterogeneity, and specific landscape metrics such as patch size of important cover types.

We also suggest that future work incorporate survivor and reproduction metrics in order to more adequately evaluate urbanization effects of moose viability. We examined habitat and space use relations, but ultimately the demographic characteristics of such populations must be examined.

Integrity of research and reporting

Research on moose was in accordance with an approved animal welfare protocol (Gothenburg, Dnr 323-2001). The author declares that they have no conflicts of interest.

Acknowledgements We thank the Swedish National Road Administration for funding this project (Vägverket Borlänge and Vägverket Region Väst), and Per-Arne Lemnell, Bengt Evertsson and Hans Skatter of TVP Positioning AB for technical advice.

\section{Appendix}

Table 3 Reclassification scheme of land cover maps used to analyze moose habitat selection in southwestern Sweden, from 2002-2005

Reclassified land cover Original land cover category
category

\begin{tabular}{|c|c|}
\hline \multirow[t]{5}{*}{ Mature coniferous forest } & $\begin{array}{l}\text { Coniferous forest } 5-15 \mathrm{~m} \text {, not on } \\
\text { lichen-rich ground }\end{array}$ \\
\hline & $\begin{array}{l}\text { Coniferous forest }>15 \mathrm{~m} \text {, not on } \\
\text { lichen-rich ground }\end{array}$ \\
\hline & $\begin{array}{l}\text { Coniferous forest }>15 \mathrm{~m} \text {, on } \\
\text { lichen-rich ground }\end{array}$ \\
\hline & Coniferous forest on mire \\
\hline & Mixed forest on mire \\
\hline
\end{tabular}

Table 3 (continued)

Reclassified land cover Original land cover category category

Mixed forest, not on mire

Mixed forest, not on glade

Deciduous forest

Deciduous forest on mire

Deciduous forest, not on mire

Deciduous forest, not on glade

Glade

Glade and boulder-rich ground

Coniferous forest $(<30 \%$ coverage)

on glade

Deciduous forest $(<30 \%$ coverage) on glade

Early successional forest Early successional forests $0-5 \mathrm{~m}$ high Clear-cut

Mire Bog

Mire

Agriculture Pasture

Arable land

Not urban park

Golf course

Urban area Communities, with $<200$ citizens

Communities, with $>200$ citizens

Camp grounds or holiday cottages

Sport facilities

Industrial estates

Provincial estates

Urban green areas

Road and railroad areas

Gravel pit

Mineral extraction

Water

Lakes and ponds, covered with vegetation

Lakes and ponds, with open water

Streams

\section{References}

Abrahamsen J, Jakobsen NK, Kalliola R, Dahl E, Wilborg L, Påhlsson L (1977) Nature-geographic regions of Norden. Nordisk Utredning Ser B 34:1-135

Anonymous (1999) Geografisk informationsbehandling - metoder och tillämpningar. byggforskningsrådet och ULI (in Swedish)

Anonymous (2004) Älgstammens storlek och sammansättning I området kring Uddevalla. Svensk Naturförvaltning AB. p8 (in Swedish)

Bergström R, Hjeljord O (1987) Moose and vegetation interactions in northwestern Europe and Poland. Swed Wildlife Res Supplement $1: 213-228$

Bowyer RT (2004) Sexual Segregation in ruminants: definitions, hypotheses, and implications for conservation and management. J Mammal 85:1039-1052

Brody AJ, Pelton MR (1989) Effects of roads on black bear movements in western North Carolina. Wildl Soc Bull 17:5-10 
Cederlund G, Okarma H (1988) Home range and habitat use of adult female moose. J Wildl Manage 52:336-343

Cederlund G, Sand HKG (1994) Home-range size in relation to age and sex in moose. J Mammal 75:1005-1012

Cederlund G, Ljungquist H, Markegren G, Stålfelt F (1980) Foods of moose and roe deer at Grimsö in central Sweden - results of rumen content analyses. Swed Wildlife Res (Viltrevy) 11:27-74

Cederlund G, Sandegren F, Larsson K (1987) Summer movements of female moose and dispersal of their offspring. J Wildl Manage $51: 342-352$

Conner LM, Plowman BW (2001) Using Euclidean distances to assess nonrandom habitat use. In: Millspaugh J, Marzluff J (eds) Radio telemetry and animal populations. Academic, San Diego, pp 275-290

Conner LM, Smith MD, Burger LW (2003) A comparison of distance based and classification-based analyses of habitat use. Ecology 84:526-531

Cox JJ, Maehr DS, Larkin JL (2006) Florida panther habitat use: new approach to an old problem. J Wildl Manage 70:1778-1785

Davies KF, Gascon C, Margules CR (2001) Habitat fragmentation: consequences, management, and future research priorities. In: Soule ME, Orians GH (eds) Conservation biology: research priorities for the next decade. Island Press, Washington, DC, pp 81-97

Engberg A (2002) Produktspecifikation av svenska corine marktäckedata. Lantmäteriet, Gävle

Franzmann AW, Schwartz CC (1997) Ecology and management of the North American moose. Smithsonian Institution Press, Washington, DC, p 733

Gasaway WC, Dubois SD, Brink KL (1980) Dispersal of subadult moose from a low density population in interior Alaska. Transactions of the North American Moose Conference and Workshop, vol 16. pp 314-337

Harveson PM, Lopez RR, Collier BA, Silvy NS (2007) Impacts of urbanization on Florida key deer behavior and population dynamics. Biol Conserv 134:321-331

Hilty JA, Lidicker WZ Jr, Merenlender AM (2006) Corridor ecology: the science and practice of linking landscapes for Biodiversity conservation. Island Press, Washington DC, p 323

Hjeljord O, Hövik N, Pederssen HB (1990) Choice of feeding sites by moose during summer, the influence of forest structure and plant phonology. Holarct Ecol 13:281-291

Hooge PN, Eichenlaub B (2000) Animal movement extension to Arcview. Version 2.0. Alaska Biological Science Center, U.S. Geological Survey, Anchorage

Hundertmark K (1998) Home range, dispersal and migration. In: Franzmann AW, Schwartz CC (eds) Ecology and management of the North American moose. Smithsonian Institution Press, Washington D.C

Janeau G, Adrados C, Girard I (2001) Is it still necessary to use GPS in differential mode since the elimination of selective availability? Conference proceeding. In: Tracking animals with GPS, Aberdeen, the Netherlands, March 2001. pp 12-13

Jenness Enterprises (2004) Nearest feature extension to Arcview. Version 3.6d. Flagstaff, Arizona

Johnson DH (1980) The comparison of usage and availability measurements for evaluating resource preference. Ecology 61:65-71

Kelsall JP (1969) Structural adaptations of moose and deer for snow. J Mammal 50:302-310

Kie JG, Bowyer RT, Nicholson MC, Boroski BB, Loft ER (2002) Landscape heterogeneity at differing scales: effects on spatial heterogeneity of mule deer. Ecology 83:530-544

Land ED, Shindle DB, Kawula RJ, Benson JF, Lotz MA, Onorato DP (2008) Florida panther habitat selection of concurrent GPS and VHF telemetry data. J Wildl Manage 73:633-639
Larkin JL, Maehr DS, Hoctor TS, Orlando MA, Whitney K (2004) Landscape linkages and conservation planning for the black bear in west-central Florida. Anim Conserv 7:23-34

Lavsund S, Nygren T, Solberg EJ (2003) Status of moose populations and challenges to moose management in Fennoscandia. Alces 39:109-130

Lopez RR, Viera MEP, Silvy NJ, Frank PA, Winsenant SW, Jones DA (2003) Survival, mortality, and life expectancy of Florida key deer. J Wildl Manage 67:34-45

Lovallo MJ, Anderson EM (1996) Bobcat movements and home ranges relative to roads in Wisconsin. Wildl Soc Bull 24:71-76

Maehr DS, Land ED, Shindle DB, Bass OL, Hoctor TS (2002) Florida panther dispersal and conservation. Biol Conserv 106:187-197

Manly BFJ, Mcdonald LL, Thomas DL, McDonald TL, Erickson WP (2002) Resource selection by animals. Springer, Great Britain, $p$ 240

Markegren G (1974) The moose in Fennoscandia. Naturaliste Can 101:185-194

Meegan RP, Maehr DS (2002) Landscape conservation and regional planning for the Florida panther. Southeast Nat 1:217-232

Mills LS (2007) Conservation of wildlife populations: demography, genetics, and management. Blackwell Publishing, Malden, $\mathrm{p}$ 407

Mladenoff DJ, Sickley TA, Wydeven AP (1999) Predicting gray wolf landscape colonization: logistic regression models vs. new field data. Ecol Appl 9:37-44

Moen AN (1976) Energy conservation by white-tailed deer in the winter. Ecology 57:192-198

Mohr CO (1947) Table of equivalent populations of North American mammals. Am Midl Nat 37:223-249

Mysterud A, Larsen PK, Ims RA, Østbye E (1999) Habitat selection by roe deer and sheep: does habitat ranking reflect recourse availability? Can J Zool 77:776-783

Nikula A, Heikkinen S, Helle E (2004) Habitat selection of adult moose (Alces alces) at two spatial scales in central Finland. Wildlife Biology 10(2):121-135

Orlando MA (2003) The ecology and behavior of an isolated black bear population in west-central Florida. M.Sc. thesis: University of Kentucky, Lexington, Kentucky, USA

Peek JM (1997) Habitat relationships. In: Franzmann AW, Schwartz CC (eds) Ecology and management of the North American moose. Smithsonian Institution Press, Washington, DC, pp 351-377

Perkins MW, Conner LM (2004) Habitat use of fox squirrels in southwestern Georgia. J Wildl Manage 68:509-513

Porter WF, Church KE (1987) Effects of environmental pattern on habitat preference analysis. J Wildl Manage 51:681-685

Pulliainen E (1974) Seasonal movements of moose in Europe. Naturaliste Canadien 101:379-392

Saunders DA, Hobbs RJ, Margules CR (1991) Biological consequences of ecosystem fragmentation: a review. Conserv Biol 5:18-32

Thurber JM, Peterson RO, Drummer TD, Thomasma SA (1994) Gray wolf response to refuge boundaries and roads in Alaska. Wild Soc Bull 22:61-67

Turner MG, Pearson SM, Romme WH, Wallace LL (1997) Landscape heterogeneity and ungulate dynamics: what spatial scales are important? In: Bissonette JA (ed) Wildlife and landscape ecology - effects of pattern and scale. Springer, New York, pp 331-348

Van Ballenberghe V, Peek JM (1971) Radiotelemetry studies of moose in northeastern Minnesota. J Wildl Manage 35:63-71

Van Beest FM, Loe LE, Mysterud A, Milner JS (2010) Comparative space use and habitat selection of moose around feeding stations. J Wildl Manage 74:219-227 